\title{
Study on the Effects of China-Georgia FTA on Economics, Trade and Industries Based on the Strategy of "One Belt and One Road"
}

\author{
Fan Yang \\ Shanghai University, No. 99 Shangda Road, P. R. China, \\ wifi0822yangfan@163.com
}

Keywords: China; Georgia; Economics; Trade; Industry; GTAP

\begin{abstract}
Based on the GTAP model, this paper is aimed to analyze the effect of China - Georgia FTA on economics, trade and industry respects of these two countries with capital accumulation model and technological progress effect. Study found that: first, China - Georgia FTA positively promotes the two countries' GDP, welfare, total import and export, and worsens Georgia's trade balance and terms of trade. Second, the main reason of promoting China's economic benefits increase is factor endowment effect while Georgia's is technological progress effect. Besides, the terms of trade effect and invest-saving effect drag on growth of Georgia's welfare. Third, China Georgia FTA mildly promote the output of each department of China with the overall fluctuation between $-0.0025 \%$ and $0.0046 \%$, while Georgia's benefit significantly. Fourth, China - Georgia FTA fully increase the import and hit the export of our country, and the Georgia's export benefits generally. Fifth, China - Georgia FTA's economics, trade and industrial effects on Georgia is significantly greater than on China.
\end{abstract}

\section{Introduction}

Entering the 21st century, with the development of the world multi-polarization, economic globalization, the diversification of civilization and social information, the closer cooperation between Asia, Europe and Africa is becoming a trend. In September and October, 2013, Chinese Chairman Xi successively put forward to build silk road economic belt and maritime silk road of the 21st century (hereinafter referred to as the "One Belt And One Road"), during a visit to mid- Asia and southeast Asia countries. This action gets the positive response of more than 60 countries, as well as the high attention of the international community and broad participation.

Georgia is very attractive to Chinese companies by its stable social situation, effective administrative operations, good investment environment, geography position advantage and free trade arrangements with the EU and other neighboring countries. At present, the government is striving to develop the infrastructure construction and manufacturing, which is China's advantage fields. China is in the world leading position and has rich experience in management in highway, railway, port, water and electricity, wind power, communications, and other areas of the infrastructure construction. The friendly cooperative relations between China and Georgia are entering into a new period in recent years, rapidly and stably. The two countries are to be in the ascendant by enhancing political mutual trust and practical and humanities cooperation. We can believe the economic and trade cooperation of China and Georgia is highly complementary and owning broad prospects.

Many authors have studied on the determinants and total effects of FTAs, like Scott L. Baier and Jeffrey H. Bergstrand (2004)[1] and (2006)[2] respectively. However, this paper is to study only one FTA, which just completed negotiation on May 13, 2017, new and promising. P. Lu (2016) [3] studied on the silk road economic belt initiative in some respects of attitude, significance and prospect. What's more, this paper aims to study the effects comprehensively with the GTAP model, which is skillfully applied to study the impacts of FTA. G. N. Zhang etc. (2012)[4], P. C. Liu (2015)[5], D. D. Hou (2016)[6], T. Nino (2016)[7], S. D. Zhou (2016)[8] and so on all have used the GTAP model to study the effects of all kinds of the FTAs. As for this paper, it will use the 
updated database and add the capital accumulation model and technological progress effect to study the China - Georgia FTA persuasively.

\section{Present Situations of Trade, Investment and the FTA}

Trade and Investment. The volume of trade between the two countries at the end of the 20th century is only $\$ 3.7$ million. However, in recent years, China have seen the potential of Georgia obviously. Due to the special relationship between Georgia and the EU (European Union contact member states), encouraging investment tax policy, and strategic location in the black sea, China's investment in Georgia now include all walks of life and expanding. Trade between the two countries is up to $\$ 813$ million in 2015. Besides, in 2014, Georgia got more than $\$ 200$ million in foreign direct investment from China. What's more, Georgia's exports to China increased amazingly by about 20 times than in 2009.In recent years, the relations of China and Georgia on economics and trade have developed sustainably and healthily, with $\$ 962$ million trade volume in 2014. In addition, China's non-financial direct investment to Georgia has been up to $\$ 530$ million in 2014 , which makes China become the third largest trading partner and the largest investment source[9].

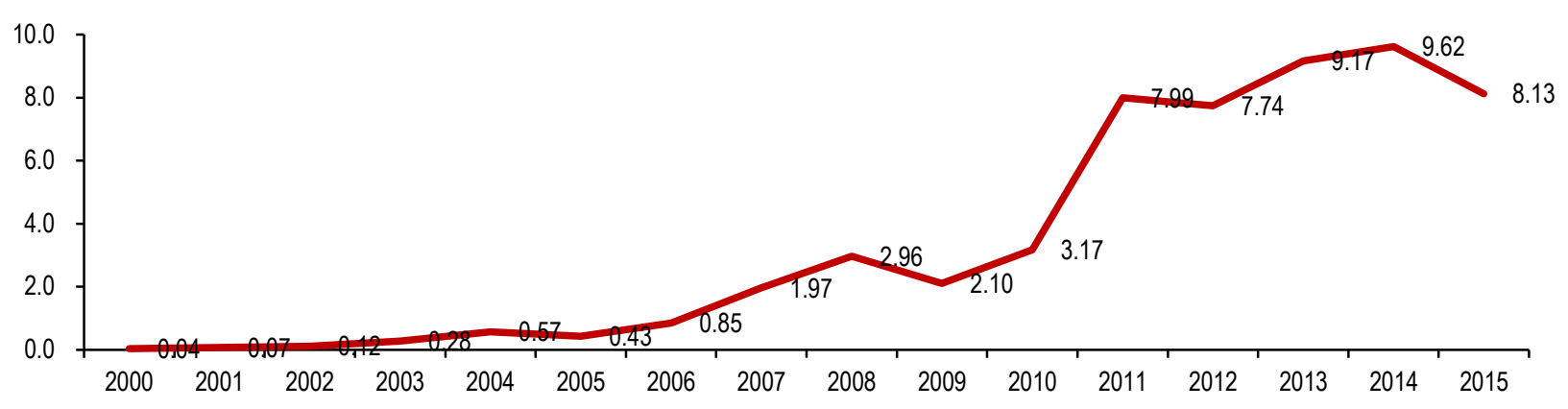

Figure 1 2000-2015 China - Georgia Bilateral Trade Value (100 Million \$)

China - Georgia FTA. On May 13, 2017, the two governments signed a "Government of the People's Republic of China and the Georgian Government Free Trade Agreement" (hereinafter referred to as "the agreement"). China - Georgia FTA negotiations started in December 2015 and substantially ended in October 2016, which just lasted less than a year. However, it has experienced intensive negotiations and consultation. Meanwhile, it is the first FTA negotiations completed by our country in Eurasia. The signed agreement will make China and Georgia's economics and trade relations turn a new page, which is beneficial to comprehensively enhance the level of practical cooperation between the two countries, increase the people's well-being, and promote the One Belt and One Road strategy and FTA strategy to put forward meaningfully. After signing the agreement, the two sides will hold firmly to complete domestic programs, striving to make effective at the end of 2017 or early 2018.

The agreement covers trade in goods, trade in services, rules of origin, customs procedures and trade facilitation, sanitary and phytosanitary measures, technical barriers to trade, trade remedy, intellectual property and areas of cooperation and such on, a total of 17 chapters. In the open level, on the one hand, about $96.5 \%$ of Georgia's products imported from China immediately implement zero tariff, cover since $99.6 \%$ of total imports from China. On the another, China to Georgia's zero tariff accounts for $93.9 \%$ of the products, covering 93.8\% of China's total imports from Georgia, with $90.9 \%$ of the products (42.7\% of total import value) immediately implement zero tariff, and the remaining $3 \%$ of the products $(51.1 \%$ of total import value) lower taxes transition for 5 years.

In the field of trade in services, the two sides to make a high-quality commitment to open service department. Among them, the Georgia satisfied China in some focused areas such as finance, transportation, natural person movement, traditional Chinese medicine and so on. Accordingly, the China satisfied Georgia in some focused areas such as tourism, shipping, law and so on. In addition, the agreement also improved trade rules further, regulating not to use third party alternative price in the anti-dumping investigation, and bright the key areas of future cooperation at the same time.[9] 


\section{Model Building}

GTAP model is a general equilibrium model with multinational and many departments developed by Purdue University. The model establishes sub models for each country or regional's behaviors like production, consumption and government spending. According to international relations commodity between trade and investment flows, the model combines each sub model into a multinational and multi-department general equilibrium model. GTAP benchmark model are assumed of perfect competition in all market and market- clearing. There are three main behavior bodies, family, government, and producer. Besides, GTAP model assumes that there are two inputs in production, factors of production and intermediate inputs. The production of the model structure can be divided into three layers of nested. In order to facilitate calculation, GTAP model set two departments, virtual international bank and the international transport, with regional savings on a fixed scale of income summary to the international Banks.

Capital Accumulation Effect. GTAP benchmark model assumes that the current basic investment will not affect production through capital accumulation, but in fact, economic policy can cause long-term capital accumulation effect. Therefore this article bases on Francois et al. (1996) study to convert them to capital accumulation model. As known, trade creation effect of FTA contributes to revenue growth, income increase produce new investments, new investments and capital growth boost GDP increase and new revenue growth, forming a benign dynamic process of economic development. Capital and investment flows relations can be expressed as

$$
\mathrm{K}_{\mathrm{t}+1}=(1-\delta) \mathrm{K}_{\mathrm{t}}+\mathrm{I}_{\mathrm{t}} \text {. }
$$

Among them, the $K_{t+1}$ and $K_{t}$ respectively represent the capital stock in the stage of $t+1$ and $t$. Besides, $I_{t}$ is the investment of $t$ stage and the delta is capital depreciation rate.Net investment is zero when the economy reaches steady state. Condition is

$$
\delta \mathrm{K}_{\mathrm{t}}^{\prime}=\mathrm{I}_{\mathrm{t}}^{\prime}=\mathrm{sY}_{\mathrm{t}}^{\prime}+\mathrm{S}_{\mathrm{t}}^{*^{\prime}}
$$

When economy is hit and then back to the steady state. Among them, $K_{t}^{\prime}, I_{t}^{\prime}, Y_{t}^{\prime}, S_{t}^{*^{\prime}}$ respectively represent for the new steady-state capital stock, investment, output and foreign savings. From the above two formula, we can get

$$
\frac{\mathrm{K}^{\prime}}{\mathrm{K}}=\frac{\mathrm{I}^{\prime}}{\mathrm{I}}=\frac{\mathrm{sY}^{\prime}+\mathrm{S}^{*^{\prime}}}{\mathrm{sY}+\mathrm{S}^{*}}
$$

Eq.3 reflects internal economic relationship between the capital stock, investment, output and foreign savings before or after the economic system changes.

Technological Progress Effect. GTAP benchmark model assumes that the technical level constant. However, FTA, promoting trade openness, will develop an advantage of division of labor, economies of scale, technology spillover and so on, improving a country's total factor productivity (TFP). The expansion of openness will promote FTA members to be more efficient through various channels. In this paper, based on GTAP9.0 database, through exports measured by world prices in the basic model (VXWD $)$, imports (VIWS 1 ) and gross domestic product (GDP), we can calculate the initial trade openness. Use updating data with capital accumulation to measure trade openness after shock. Thus we can calculate every FTA members' change rate of trade openness after in effect. According to the average elastic index that the trade openness changes each $1 \%$, total factor productivity change $0.15 \%$ (referring to the simulation results conducted by Penn World Table, the World bank and other institutions in 109 countries around the World with 1980-2011), shock on capital accumulation effect model with technology progress effect to enable more realistic simulation on FTA economic effects of regional integration.[10]

\section{Results and Analysis}

Macroeconomics Level. According to the specific needs, we will divide GTAP9 140 locations in the database into six areas: China, Georgia, Asia, America, Europe and the rest of the world with the GTAP original 57 industry classification. Relying on six areas, 57 department GTAP model, 
considering the capital accumulation effect and technology progress effect, we run the simulation of China - Georgia FTA. Full results of the simulation show that: (1) From the point of GDP and economic welfare, China - Georgia FTA with full implementation makes China's GDP grow $0.0003 \%$, welfare increase $\$ 30$ million, Georgia's GDP grow $0.16 \%$, welfare increase $\$ 15$ million. (2) From the point of trade flows, the China - Georgia FTA will make Chinese imports and exports increased by $0.0009 \%$ and $0.0005 \%$ respectively, Georgia's imports and exports increased by $0.46 \%$ and $0.19 \%$ respectively, with an increase of $\$ 2$ million of China's trade balance and a decrease of $\$ 3$ million of Georgia's. (3) From the perspective of the changes of the terms of trade, China's terms of trade improved slightly, and Georgia's terms of trade deteriorate with the deterioration of trade competitiveness. We can conclude that China - Georgia FTA will promote the two countries' GDP, welfare and total import and export, and the degree of promoting on Georgia will be more greater than China.

Table 1 The Potential Effects of China - Georgia FTA on Economics, Trade and Welfare

\begin{tabular}{ccccccc}
\hline & Qgdp $(\%)$ & EV (million \$) & qxwreg $(\%)$ & qiwreg $(\%)$ & DTBAL (million & tot $(\%)$ \\
\hline China & 0.0003 & 30 & 0.0005 & 0.0009 & 2 & 0.0003 \\
Georgia & 0.1591 & 15 & 0.4558 & 0.1935 & -3 & -0.0774 \\
\hline
\end{tabular}

The welfare of the China - Georgia FTA, as shown in Table 2, show that: (1) In China - Georgia FTA, the main reason of promoting China's economic welfare increase is the factor endowments, technology progress, the terms of trade effect. What's more, factor endowment effect accounts for the largest proportion in contribution to welfare increase and resource allocation effect makes minimal contribution. (2) In China - Georgia FTA, the main reason of promoting Georgia's economic welfare increase is the technology progress effect, and the terms of trade effect and investment saving effect drag on the growth of welfare. Through the calculated value of TFP, we can see that Georgia technical improvement is significantly greater than China, who benefits remarkably.

Table 2 Welfare Decomposition of China - Georgia FTA（Million \$)

\begin{tabular}{ccccccc}
\hline WELFARE & 1 alloc_A1 & 2 endw_B1 & 3 tech_C1 & 5 tot_E1 & 6 IS_F1 & Total \\
\hline 1 China & 3 & 8 & 7 & 7 & 6 & 30 \\
2 Georgia & 4 & 5 & 11 & -3 & -3 & 15 \\
\hline
\end{tabular}

Trade Level. Trade creation effect and trade diversion effect of FTA will gradually influence the trade structure and industrial competitiveness of FTA members. Therefore, after implementation, the member states will taking full advantage of the integration to actively adjust the industrial structure and enhance the competitiveness of their economies. The full implementation of the FTA is expected to make the import and export in China increased by $0.0009 \%$ and $0.0005 \%$ respectively, however, there is a big difference between different industries (Table 3).From the point of exports, both agricultural and manufacturing, China's export is obviously shocked, while the Georgia benefits. The bigger export growth of our country in the agricultural products is Meat Products Nec $(0.206 \%)$, Vegetables, Fruit and Nuts $(0.0416 \%)$, Food Products Nec $(0.0131 \%)$ and other departments in sequence. Another side, Raw Milk (-0.0095\%), Wool, Silk-Worm Cocoons $(-0.0099 \%)$, Wheat $(-0.0111 \%)$ and other export sectors will have minor shocks. As for manufacturing, the bigger export growth of our country is, in turn, Mineral Products Nec $(0.0217 \%)$, Metal Products $(0.0162 \%)$, Chemical, Rubber, Plastic Products $(0.0026 \%)$ and other departments. Another side, Transport Equipment Nec (-0.0024\%), Coal (-0.0024\%), Leather Products (-0.0025\%) and other export sectors will have minor shocks. From the point of imports, China's imports increased generally that the largest import of agricultural is Beverages and Tobacco Products $(0.0112 \%)$ and the largest import of manufacturing is Wearing Apparel $(0.0019 \%)$. Last year, China's imports of wine beverages reached more than 120 bottles, rising more than $30 \%$, one of the 
fastest growths.

Table 3 Effects of Fully Implemented China - Georgia FTA on Trade (TOP 3)(\%)

\begin{tabular}{|c|c|c|c|c|c|c|c|c|c|c|c|c|c|c|c|c|}
\hline & \multicolumn{4}{|c|}{ China(Agricultural) } & \multicolumn{4}{|c|}{ China(Manufacture) } & \multicolumn{4}{|c|}{ Georgia(Agricultural) } & \multicolumn{4}{|c|}{ Georgia(Manufacture) } \\
\hline & & port & & sport & & port & & port & & ort & & ort & & & & ort \\
\hline \multirow[t]{3}{*}{+} & b_t & 0.0112 & & 0.206 & wap & 0.0019 & $\mathrm{nmm}$ & 0.0217 & $v_{-} f$ & 1.70 & vol & 2.14 & $\mathrm{nmm}$ & 1.03 & & 2.86 \\
\hline & v_f & 0.0091 & v_f & 0.0416 & $\mathrm{nfm}$ & 0.0016 & fmp & 0.0162 & omt & 1.28 & pcr & 2.07 & fmp & 0.53 & ome & 1.33 \\
\hline & $\mathrm{pdr}$ & 0.0073 & ofd & 0.0131 & lum & 0.0015 & crp & 0.0026 & ofd & 0.51 & wol & 1.35 & $\mathrm{nfm}$ & 0.41 & $\mathrm{nfm}$ & 1.26 \\
\hline \multirow[t]{3}{*}{ - } & & & $\mathrm{rmk}$ & -0.0095 & & & otn & -0.0024 & mil & -0.10 & gro & -0.01 & ppp & -0.02 & gas & -0.08 \\
\hline & & & wol & -0.0099 & & & coa & -0.0024 & $\mathrm{cmt}$ & -0.10 & ocr & -0.16 & otn & -0.17 & & \\
\hline & & & wht & -0.0111 & & & lea & -0.0025 & wol & -0.48 & & & coa & -1.79 & & \\
\hline
\end{tabular}

However, effects on Georgia's import and export of most departments significantly are greater than our country, with the full implementation of China - Georgia FTA making the Georgian import and export increase $0.46 \%$ and $0.19 \%$ respectively. Similarly, there is also a big difference between different industries (Table 3). From the point of exports, the export departments of Georgia commonly benefit and those growths are bigger. Among them, the bigger export growths of the agricultural products, in turn, is Vegetable Oils and Fats $(2.14 \%)$, Processed Rice $(2.07 \%)$, Wool $(1.35 \%)$. Another side, only two departments - Cereal Grains Nec $(0.01 \%)$ and Crops Nec $(0.16 \%)$ -will have minor shocks. As for manufacturing, the bigger export growths, in turn, is Coal (2.86\%), Machinery and Equipment Nec (1.33\%), Metals Nec (1.26\%) and other departments. Only one department - gas $(0.08 \%)$ - will have minor shocks. From the point of imports, the Georgia's bigger export growths of the agricultural products, in turn, is Vegetables, Fruit and Nuts (1.71\%), Meat Products Nec (1.28\%) etc. Dairy Products, Bovine Meat Products, Wool and other departments' import will decrease to some degree. And in manufacturing department, Mineral Products Nec $(1.03 \%)$, Metal Products $(0.53 \%)$ and so on have more imports comparatively. Another side, departments such as Paper Products and Publishing (-0.02\%), Transport Equipment Nec (-0.17\%) and Coal $(-1.79 \%)$ have decrease at different degrees.

Industrial Level. Effects of China - Georgia FTA on our country are relatively mild, with the overall fluctuation between $-0.0025 \%$ and $-0.0046 \%$ (Fig.2, Fig.3). The most beneficial agricultural products is Meat Products Nec $(0.0046 \%)$ and the most injured is Wool (-0.0025\%). In industrial products, the most beneficial product is Metal Products $(0.0029 \%)$ and the most injured is Leather Products $(-0.0014 \%)$. However, there is obviously difference in the impacts of China Georgia FTA on Georgia (Fig.4, Fig.5). In agricultural products, output of Vegetable Oils and Fats is as high as $2.10 \%$, and then, the output of Processed Rice, more greatly increase, is up to $1.07 \%$. What's more, Cereal Grains Nec (0.67\%), Sugar Cane and Sugar Beet (0.36\%), Plant-Based Fibers $(0.26 \%)$ etc. have different levels of growth, while the injured departments only Food Products Nec $(-0.14 \%)$ and Meat Products $(-0.73 \%)$. The biggest output department of manufacturing products is Metals Nec, which is up to $1.24 \%$. The rest, such as Machinery and Equipment Nec $(0.83 \%)$, Ferrous Metals (0.81\%), Electronic Equipment (0.72\%), Wearing Apparel (0.61\%) have larger output comparatively. There is only three sectors shocked, Coal $(-0.37 \%)$, Mineral Products Nec (-0.52\%), Metal Products (-1.22\%).

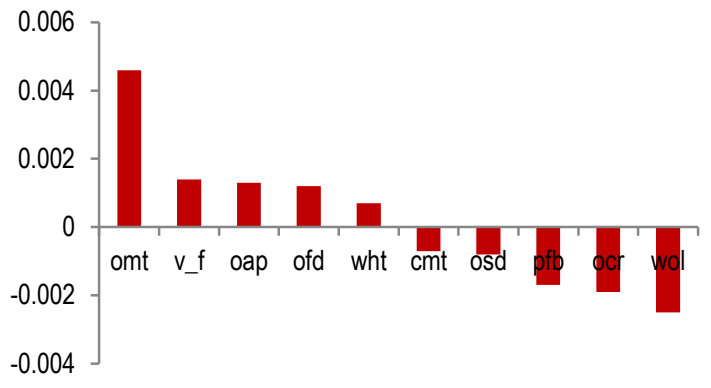

Figure 2. China Agricultural Products TOP $5(\%)$

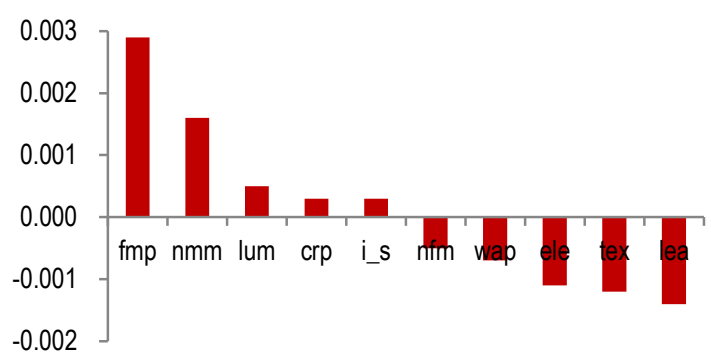

Figure 3. China Manufacturing Products TOP $5(\%)$ 


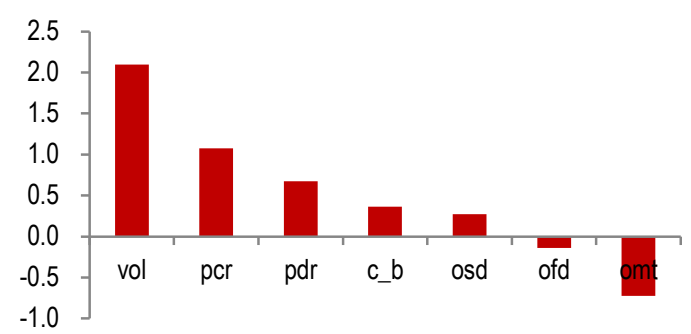

Figure 4. Georgia Agricultural Products TOP $5(\%)$

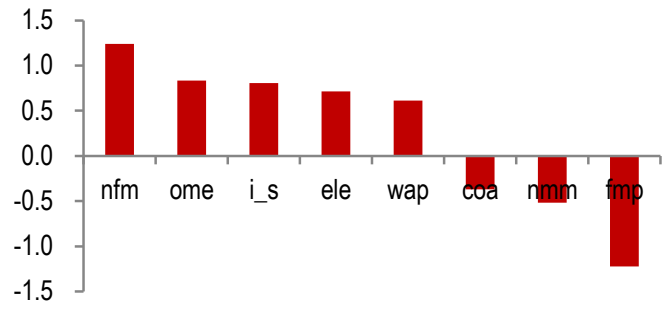

Figure 5. Georgia Manufacturing Products TOP $5(\%)$

\section{Conclusions}

This paper has conducted simulations to analyze the impacts of China - Georgia FTA on economics, trade and industries, considering the capital accumulation effect and technology progress effect. The main conclusions are as follows: first, China - Georgia FTA positively promotes the two countries' GDP, welfare, total import and export, and worsens Georgia's trade balance and terms of trade. Second, the main reason of promoting China's economic benefits increase is factor endowment effect while Georgia's is technological progress effect. Besides, the terms of trade effect and invest-saving effect drag on growth of Georgia's welfare. Third, China - Georgia FTA mildly promote the output of each department of China with the overall fluctuation between $-0.0025 \%$ and $0.0046 \%$, while Georgia's benefit significantly. Fourth, China - Georgia FTA fully increase the import and hit the export of our country, and the Georgia's export benefits generally. Fifth, China Georgia FTA's economics, trade and industrial effects on Georgia is significantly greater than on China. It's worth noting that under the strategy "One Belt and One Road", the future of China Georgia FTA will be more and more brighter.

\section{References}

[1]. [Scott L. Baier and Jeffrey H. Bergstrand: Journal of International Economics, Vol. 64 (2004) No.1, p.29-63.

[2].Scott L. Baier and Jeffrey H. Bergstrand: Journal of International Economics, Vol. 71 (2006), p.72-95.

[3].P. Lu: Russian Journal, (2016) No.5, p.75-83. (In Chinese)

[4].G. N. Zhang, K. M. Chen and S. F. Yang: Economics (quarterly), (2012) No.3, p.873-892. (In Chinese)

[5].P. C. Liu: Modern Japan's Economy, (2015) No.1, p.43-54. (In Chinese)

[6].D. D. Hou: International Economics and Trade Research, (2016) No.8, p. 15-25 (In Chinese)

[7].T. Nino: Design, The current situation of the relationship between China and Georgia, analysis and future prospects. (Ph.D., Central China Normal University, China 2016)

[8].S. D. Zhou, X. Xiao and J. Yang: International Trade Issues, (2016) No.5, p.116-129 (In Chinese)

[9].Information on http://fta.mofcom.gov.cn

[10]. Japan's chief cabinet secretary TPP policy headquarters: The policy effect analysis the TPP agreement. (In Japanese) 